7s. $3 d$. by post). The exhibition will be open at the following times : April 13, 10.30 a.m.-8 p.m. (Fellows and Press only, 10.30 a.m.-2 p.m.) ; April 14-16, 10 a.m.-8 p.m.; April 17, 10 a.m.-5 p.m. Application for tickets, which are of various types, available for part or all of these times, should be made as soon as possible to the Exhibition Secretary, Physical Society, 1 Lowther Gardens, Prince Consort Road, London, S.W.7, from whom all further particulars can be obtained.

\section{Electronic Instruments in Atomic Energy: Course at Harwell}

A SPECIALIZED course on the design, use and maintenance of electronic instruments used in nuclear physics, radiochemistry and in work with radioisotopes will be held at the Isotope School of the Atomic Energy Research Establishment, Harwell, during March 16-20. The course will be limited to twelve people who are physicists or electronic engineers holding a degree or equivalent qualification, and will include lectures and practical work on counters, D.C. and pulse amplifiers, coincidence units, scalers and rate-meters. The instructional staff will be drawn from the Atomic Energy Research Establishment, but the Isotope School is outside the security fence and the subject-matter will be entirely unclassified. The foe for the course is 12 guineas, and living accommodation (at Buckland House, near Faringdon, which is one of the senior staff hostels of the Establishment), transport and morning and evening meals will be provided at a charge of 7 guineas. Application forms can be obtained from the Electronics Division, A.E.R.E., Harwell, near Didcot, Berks.

\section{Royal Society Lectures for 1953}

Royal Society Lectures for 1953 will be delivered as follows: Croonian Lecture, on June 11, by Sir Ronald Fisher, professor of genetics, University of Cambridge; Bakerian Lecture, on May 7, by Prof. N. F. Mott, professor of physies and director of $\mathbf{H} . \mathbf{H}$. Wills Physics Laboratory, University of Bristol; Ferrier Lecture, on December 10, by Dr. F. M. R. Walshe, consulting physician to University College Hospital and to the National Hospital for Nervous Diseases; Wilkins Lecture, on March 5, by Sir Harold Hartley ; Leeuwenhoek Lecture, on November 5, by Dr. K. M. Smith, director of the Plant Virus Research Unit (Agricultural Research Council), Molteno Institute, University of Cambridge.

\section{Announcements}

THE Council of the Royal Society has appointed Sir James Chadwick as the Rutberford Lecturer for 1953 ; he will deliver the Lecture at McGill University, Montreal, in the autumn. This is the second Rutherford Lecture to be given under the terms of the Rutherford Memorial Fund, the first having been delivered last year in New Zealand by Sir John Cockcroft.

The Guthrie Lecture of the Physical Society, which is given annually in memory of the founder of the Society, will be delivered on March 13 in the Lecture Theatre of the Science Museum, Exhibition Road, London, S.W.7, at 5 p.m., by Prof. M. Born, who will speak on "The Conceptual Situation in Physics and its Prospects of Development".

A Centenary Lecture of the Chemical Society will be given by Prof. A. Tiselius, of Uppsala University, at 7.30 p.m. on February 26 in the Lecture
Theatre of the Royal Institution, Albemarle Street. London, W.1. The subject of the Lecture will be "Some Applications of the Separation of Large Molecules and Colloidal Particles".

A Centenary Exhibition of prints from the Royal Photographic Society's Permanent Collection and photographic apparatus collected by the Society and the Science Museum has been arranged at the Science Museum, Exhibition Road, London, S.W.7, and in the Society's House, at 16 Princes Gate, London, S.W.7. The Exhibition will be open from February 17 until March 28.

AT the general monthly meeting of the members of the Royal Institution, held on February 2, Mr. Stanley Robson was elected serretary to fill the vacancy caused by the resignation of Prof. A. O. Rankine.

Mr. A. B. Duncan, chairman of the finance committee and a member of the Scottish committee of the Nature Conservancy, has been appointed chairman of the Conservancy in succession to Sir Arthur Tansley.

Mr. M. W. Thring has been appointed an assistant director of research of the British Iron and Steel Research Association. He will continue as head of the Physics Department of the Association.

Mr. F. E. BRUCE has been appointed to the University readership in public health engineering tenable at the Imperial College of Science and Technology, London. The degree of D.Sc. (Engineering) of the University of London has been conferred on Mr. Stanley Whitehead.

THE third annual conference of the Ergonomics Research Society will be held in the Department of Human Anatomy, University of Oxford, during April 13-16, and will take the form of a symposium on "Human Performance: its Measurements and Limitations". The conference will be under the chairmanship of Prof. W. E. Le Gros Clark. A fee of $30 \mathrm{~s}$. is charged for those who are not members of the Society. Limited accommodation is available in Brasenose College. Enrolment forms (to be completed at the latest by March 31) and further information can be obtained from H. Murrell, Spinneys, Marlpit Lane, Headless Cross, near Redditch, Worcs.

A conference marking the twenty-fifth anniversary of the Sub-Committee on Dust Technology of the Verein Deutscher Ingenieure will be held in Essen during March 26-27. After an introduction by the chairman, Robert Meldau, a number of papers will be read, including one by Prof. P. Jordan (University of Hamburg) on the distribution of fine dust in new theories on world creation, another by Prof. Correns (University of Göttingen) on dust in the formation of sedimentary rocks, and seven other papers dealing with various aspects of dust technology.

THE first Marjory Stephenson Memorial Lecture will be given by Dr. D. D. Woods at the Royal Institution, Albemarle Street, London, at 6 p.m. on April 13, his subject being "The Integration of Research on the Nutrition and Metabolism of Microorganisms". The Lecture is open to the public. The Marjory Stephenson Memorial Fund is administered by the Society for General Microbiology, and the Lecture will be given during the sixteenth general meeting of the Society. Further details can be obtained from the general secretary of the Society, Dr. J. G. Davis, 52 London Road, Reading, Berks. 